\title{
Failing Institutions Are at the Core of the Euro Crisis
}

\author{
Alojzy Z. Nowak ${ }^{1}$ \\ Yochanan Shachmurove ${ }^{2}$
}

October 19, 2012

\begin{abstract}
The European Union was created to promote economic, cultural, and regional prosperity. However, the Global Financial Crisis demonstrates that its economic institutions are flawed. While each sovereign state in the Eurozone forfeits the control of its money supply, the lack of a common fiscal institution allows individual countries to pursue their own political and financial agendas. The on-going economic hardship emphasizes the critical role of economic and political institution ions. This paper analyzes both beneficial and perverse incentives of joining the European Union, discusses the consequences of deficient economic institutions and provides potential solutions towards the alleviation of the crisis.
\end{abstract}

JEL Classification: B52; F00, F01, F33, K0

Key Words: European Union; Eurozone; Harmonized Index of Consumer Prices; Portugal, Ireland, Greece and Spain (PIGS); Fiscal Union; Financial Crises; Maastricht Criteria; Maastricht Treaty; Exchange Rate; Euro

\footnotetext{
${ }^{1}$ Alojzy Z. Nowak is the Vice-Rector of Warsaw University.

${ }^{2}$ Yochanan Shachmurove (yshachmurove@ccny.cuny.edu), Department of Economics and Business, The City College of The City University of New York.
} 


\section{Failing Institutions Are at the Core of the Euro Crisis}

\section{Introduction}

The current fiscal problems confronting the European Union ${ }^{3}$ are compromising the future of the Eurozone. ${ }^{4}$ Key players in the global economy are questioning whether European politicians are able to successfully cope with these challenges. The breadth and continuity of the crisis highlight the urgency of this issue. This paper describes and analyzes the impacts of the Euro crisis on the countries that are members of the European Union. Specifically, the paper investigates the effects on the countries that join the European Union and their exports, imports and capital account performances vis-à-vis their European partners as well as the world economy. The study details the Eurozone trade with the world and describes the consequences of the Financial Crisis on the European Union.

The paper is organized as follows. Section 2 reviews literature. Sections 3 and 4 present the disadvantages and advantages, respectfully, of joining the European Union (EU). Section 5 describes the EU today. Section 6 details the Eurozone debt. Section 7 describes the admission process to the Eurozone. Section 8 discusses the financial crisis and the European Union. Section 9 introduces a few Eurozone scenarios. Section 10 concludes.

3 The European Union is an economic and political union comprised of the following members: Austria, Belgium, Bulgaria, Cyprus, The Czech Republic, Denmark, Estonia, Finland, France, Germany, Greece, Hungary, Ireland, Italy, Latvia, Lithuania, Luxembourg, Malta, The Netherlands, Poland, Portugal, Romania, Slovakia, Slovenia, Spain, Sweden, and the United Kingdom.

${ }^{4}$ The Eurozone, also known as the Euro Area, Euro land, or Euro Monetary Union, is comprised of the following members: Austria, Belgium, Cyprus, Estonia, Finland, France, Germany, Greece, Ireland, Italy, Luxembourg, Malta, the Netherlands, Portugal, Slovakia, Slovenia, and Spain. 


\section{Literature Review}

The theory of an economic monetary union was advanced as early as 1961 by Mundell with his classic paper, "The Theory of Optimum Currency Areas," and subsequently by McKinnon (1963) and Kenen (1969). Mundell defined optimum currency area as a geographical unit closely integrated through international trade and factor movements such as labor and capital. The theory states that fixed exchange rate systems are most appropriate for these areas. Mundell recognized the costs of adopting a single currency and made the case for the establishment of a common fiscal authority to facilitate the transfer of resources between members hit by asymmetric economic shocks when mechanisms such as the wage and price flexibility and labor mobility did not function. One of the main failures of the euro zone at this point is the inability to create an institution that will coordinate fiscal policies and will have the power to conduct such a coordinated fiscal policy. All of the early contributors to the theory emphasize that the choice of exchange-rate regime should depend on the structural characteristics of a country, such as its size, openness, and its product diversification. In other words, the respective cases for either floating or fixed-exchange rates (or an intermediate regime) are not equally applicable to all economies, so that the exchange-rate regime that a particular country chooses may matter a great deal for macroeconomic performance.

Historical comparison of the formation of past fiscal unions reveals crucial implications for the Eurozone. In the case of the United States, Argentina, and Germany, the fiscal unions were preceded by political ones, and the institutional development associated with fiscal union was preceded by exceptional events (Bordo and James, 2010). Friedman (1953) set forth the basic core of what subsequently emerged as optimum-currency-area analysis. Friedman understood that, in an imperfect world, separate currencies and flexible exchange rates among different areas would facilitate adjustment among the areas (Friedman, 1958). Applying this analysis to the Eurozone where countries use differing criteria, and in 
the presence of countries being subjected to asymmetric shocks, labor mobility, wage and price flexibility, and risk-sharing mechanisms, all result in empirical evidence to support the establishment of a supplementary fiscal union (Bordo and James, 2010). Failing to do establish such institutions is the hallmark of the current multiple financial and economic crises.

Authors, Lerner (1947), Friedman (1953), Meade (1951), and Scitovsky (1958) anticipated the basic tenets of optimum-currency-area analysis. In analyzing the effectiveness of inter-regional adjustment within countries, these authors drew attention to the crucial role played by single, central monetary and fiscal authorities and the free movement of goods and factors of production among regions in economic adjustment. Cesarano (2006) argued that the above-mentioned authors believed that the classical adjustment mechanism would be effective in the absence of exchange-rate variations among separate national currencies. In other words, a single monetary policy combined with the free movement of labor, capital and goods would negate the need for exchange-rate variations; the logical extension of this line of reasoning is that a single currency would be optimal for the global economy.

\section{Disadvantages of Joining the Eurozone: Focus on Poland}

The seventeen nations which compose the Eurozone have been in the midst of a financial crisis for the past decade. Several countries are in fiscal quagmires that threaten to take the entire zone's economy down. This fiscal crisis has raised serious questions about the viability of the euro as well as the entire system that is the most ambitious step that have ever taken toward peaceful European integration.

In late 2009, investors feared of a sovereign debt crisis after public and private debt rose and government debt was downgraded in several countries. Each country had its own reason to be worried. In many countries, property bubble debts were transferred to sovereign 
debt as a result of banking system bailouts and government responses to their slowing economies as a result of the post-bubble.

Being outside of the Eurozone, Poland has not experienced the most serious fiscal crisis. While Poland does not play the most prominent role in the European Union (EU), representatives of Polish financial institutions and business circles actively participate in drafting proposals to improve the economic condition of the European Union and offer solutions for prevention of future crises. The task, however, is not an easy one. First, the EU itself is far from uniform; its member states feature diverse stages of economic, financial, social and political development, which is reflected in the goals each pursues. Individual member states offer different visions concerning the direction that the European Union should follow. Some of them emphasize the need for more independence for its individual member states, while others are keen on further integrating the EU.

The EU nations are fragmented in their approach to the Eurozone. For much of 20102012, political efforts were focused on preventing contagion to other countries and restoring faith in the long-term sustainability of the monetary union. As things stand, it is unclear whether European policy-makers have succeeded. Some believe that the euro area countries have done little more than apply words rather than actions to cover the fault-lines exposed by the crisis and that the zone's internal contradictions condemn the single currency bloc to an eventual break up. Even those who dismiss such an outcome as unlikely concede that the euro area will be able to escape a wave of sovereign debt defaults that could push already weakened banking systems into insolvency.

Poland, making it clear that it does not act out of national self interest alone, acknowledges the need to consider the interests of the entire EU. Poland recognizes that the proposals of the largest member states of the EU to overcome the crisis are unrealistic. 
Polish economists acknowledge that, although economic sovereignty is costly, Poland benefited from remaining outside the Eurozone. The country applied the fundamental tools of monetary policy (money supply, interest rates, cash reserve, exchange rate) with relative freedom throughout during the global financial crisis. Mundell (2011) claims that the loss of control over such tools is a main cost of joining the Eurozone.

By participating in a monetary union, a country is essentially forfeiting its right to determine how much its currency is worth. Unfortunately for that country, its lack of ability to exercise its own monetary policy means losing the power to impose inflation to its advantage, namely to decrease public debt. Such practices were used by France in the 1920's to wipe away $70 \%$ of its public debt. Some believe that the result of the loss of this freedom to control currency is a much higher risk of default in euro countries over non-euro countries. ${ }^{5}$ He states that a country can always increase its money supply in order to repay its debt as long as this debt is in its own national currency. This method of curing public debt can cause currency depreciation and inflation, but a nation free to conduct its own monetary policy is free to manage these risks. This predicament is personified very well by the public debt crisis in Greece, where unsustainable public sector wages and pension commitments caused the national debt to substantially increase. Because the Eurozone is a monetary union without fiscal union, countries share a currency but maintain different tax and public pension rules. This has contributed to the crisis and harmed the ability of European leaders to respond. Additionally, matters putting the solvency of the state at risk also endanger the solvency of the banking systems. European banks own a significant amount of sovereign debt a negatively reinforcing relationship.

However, not all implications of a common currency are negative. A stable exchange rate means less uncertainty about how much the currency will be worth, making it a more

\footnotetext{
${ }^{5}$ See, for example, Szyska, Adam, Warsaw School of Economics, "Economic and Behavioral Aspects of the Euro Crisis," Unpublished, 2012.
} 
appealing investment. Currency control, however, is not the only thing a nation needs to sacrifice upon joining the Eurozone. European countries must also comply with other conditions, such as keeping up with their national debt and expenditures while creating a competitive job market as well as increasing overall productivity. The cost of joining the Euro is truly a very costly one. England for example, experienced "The Black Wednesday" losing $£ 3.3$ billion as a result of its efforts to join the EU’s Exchange Rate Mechanism (ERM). England later abandoned its efforts to join the ERM, but the devastation could not be undone. That the Euro has been mired in the European sovereign debt crisis since 2009 is further testament to the riskiness of joining the currency union. As a result, many are skeptical of the euro and the EU. The other factor that makes the euro zone a costly and dangerous risk is that the "euro zone is lacking in the support of 'institutional paraphernalia' as well as mutual bonds of solidarity of a state."

On the other hand, looking at the recent historical context, the pressure to join the Eurozone was too high. Many countries considered their Eurozone membership as a sign of prestige and were more likely to spend more than they could afford. They assumed that default was less likely since the effect would be too serious for other European countries. Greece, for example, did not show enough effort to reform its economy. Unlike its European counterparts, Greece could not create more jobs. Government expenditure un-balanced with investment and economic growth became a huge problem. It took its toll in 2010 and now the same scenario is happening once again, only this time with economic reform, which Greece failed to make in the past despite its promises. Some claim that Greece must now cut its expenditures to balance its budget and cover its debt. This policy is pro-cyclical, meaning it encourages fiscal austerity in a time of recession. The policy is based on the theory that austerity and high unemployment will lower labor costs, which will make the country's exports more competitive and lead to recovery. Supporters hail the policy for controlling 
inflation; critics note the human costs of higher unemployment. However, many creditor countries also share the cost of salvaging what is left in order to avoid default in Greece. Eurozone members have to take the fall and save other Eurozone members so they can all survive; otherwise, they will all fail. They must work in-sync and increase their growth rate or it will be impossible for the Euro to maintain its stability.

Crises such as the one occurring in Greece could have been avoided had Greece strictly adhered to the criteria of the Masstricht treaty. The Maastricht Treaty of 1992 led to the creation of the euro and was responsible for the creation of the pillar structure of the European Union. The convergence criteria, based on Article 121(1) of the ECT of the treaty are mandatory for the EU members to be inducted into stage three of the EMU and adopt the Euro as their currency. One criterion states that the ratio of the rate of growth of annual government debt to GDP must not exceed 3\%. A second criterion is that the ratio of government debt to GDP must not exceed $60 \%$. Had Greece been forced to comply with such requirements, it may not have even joined the Euro in the first place. However, a clause in the treaty permits a country to join as long as its violation of the criteria is only temporary, and the country is showing signs of improvement. This exception to the rule became the norm as time went on. By 2010, the average debt to GDP ratio in the Euro zone was $85.5 \%$, and the average deficit was $6.3 \%$.

The real problem with the budget deficit numbers was that they were manipulated (see, for example, De Grauwe, 2009). In the specific case of Greece, there was fraud involved and in the cases of Belgium, France and Italy, creative accounting was the ploy at hand. For instance, budget authorities pilfered pensions and liabilities and tampered with assets. All of this occurred while the EC gave its stamp of approval! Thus, some nations of the euro zone obtained free passage into the EU due to literally cooked-up numbers. Heavy politics has also 
been involved in the use of the Maastricht Treaty in the EU. Accordingly, the political objective seems to be to use the treaty to slow down the euro zone.

\section{Advantages of Joining the Eurozone}

Nevertheless, being a member of the Eurozone increases a country's reliability, enhancing a country's investment grade and improving its prospects for foreign capital inflow. Joining the Eurozone means reduced exchange rate costs as the currency is common. Also, lower prices across the euro-zone benefit consumers due to greater price transparency (Anderton, 1977). This gives relief to businesses in the form of drastically reduced costs and increased investments. Inflation is another issue tackled by a single currency. The UK has especially benefitted from reduced inflation brought by the euro. In addition, the uncertainty due to exchange rate fluctuations is eliminated.

Other benefits stem from the fact that being a part of a monetary union lends itself to greater efficiency. For example, the Eurozone experiences lower interest rates with less fluctuation in times of distress relative to other regions, because it is in less danger of inflation. Figures 1 and 2 display the Euro Area interest rate and Harmonized Index of Consumer Prices (HICP), inflation rate. 


\section{Euro Area Interest}

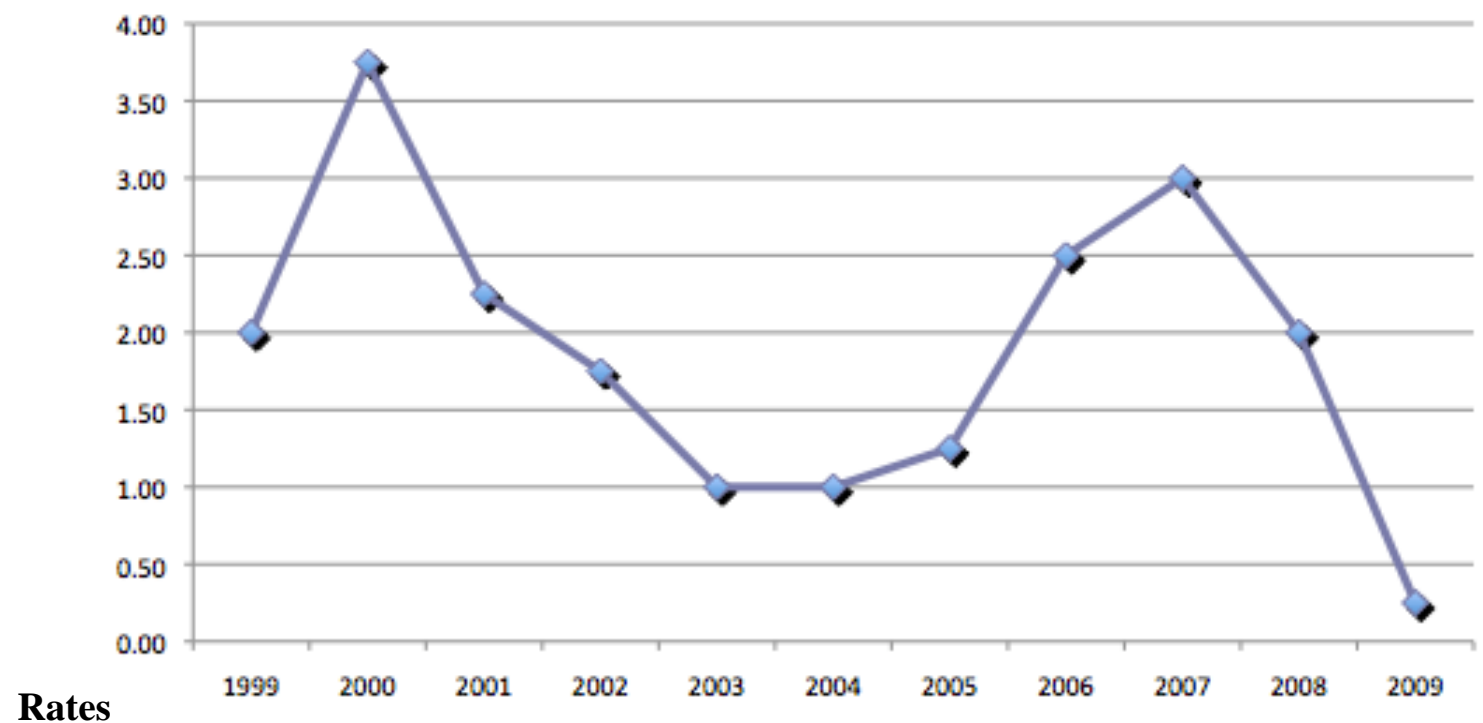

Figure 1: Euro Area Interest rate, Official Deposit Rate 1999-2009

Source: Central Bank Interest Rates-Annual Data. (2012, January). ECB Statistical Data Warehouse. Retrieved February 26, 2012, from http://sdw.ecb.europa.eu/home.d

\section{Harmonized Index of Consumer Prices}

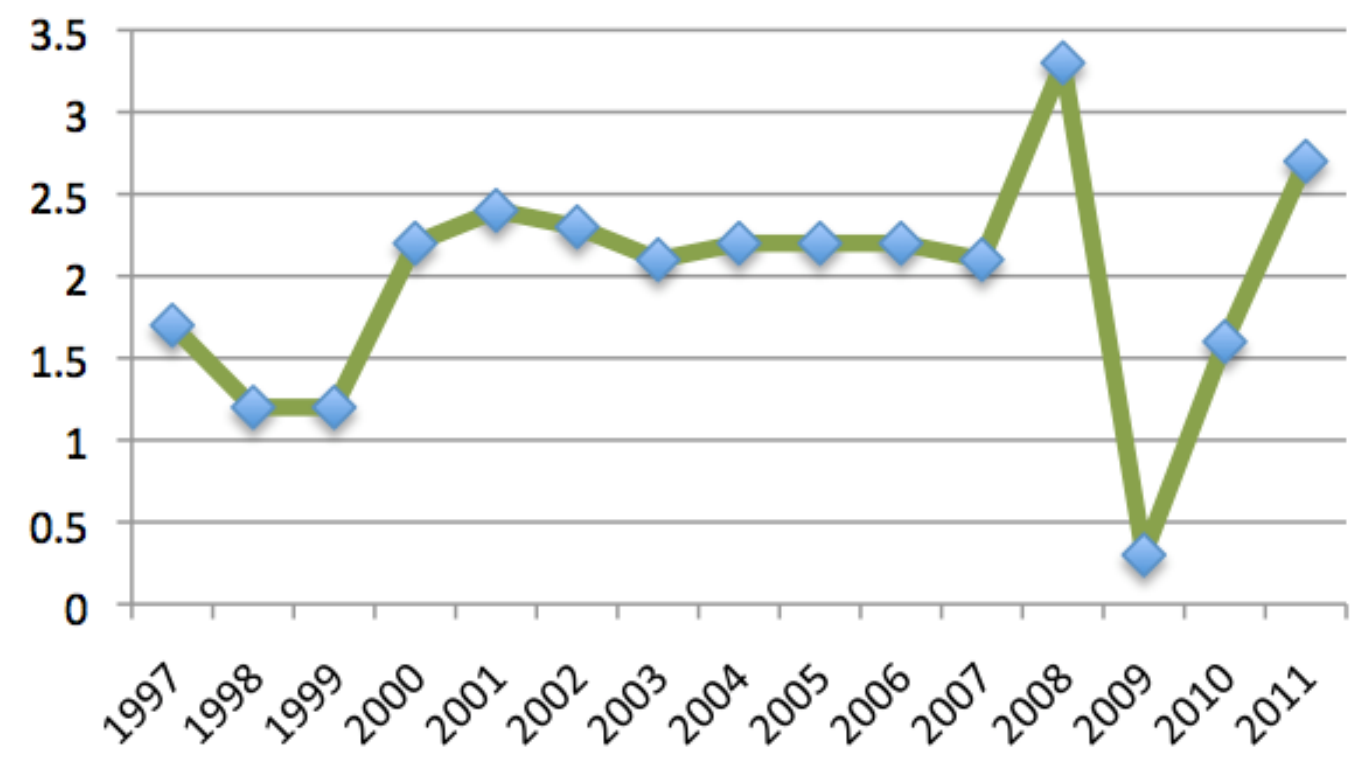

Figure 2: Euro Area Inflation Rates 1997-2011

Source: Euro area HICP statistics. (2012, January). ECB Statistical Data Warehouse. Retrieved February 26, 2012, from http://sdw.ecb.europa.eu/home.do 
Within the EU, there are reduced transaction costs on trade because member states are under a common currency. These factors enable faster convergence of the Polish economy to that of the leading Western countries within the Eurozone. It is quite obvious that it will take reliable and extensive economic and financial analysis to evaluate the pros and cons of Poland's current standing outside the Eurozone. However, in the long run, the necessity of Poland's Eurozone membership is indisputable, with the only question being when Poland will join. Belonging to the group of countries using the common European currency is the best anchor for a national economy.

\section{The EU Today}

The European Union is an economic and political entity and a confederation of 27 member states which are located primarily in Europe. The EU traces its origins to the European Coal and Steel Community, the European Economic Community, and the European Atomic Energy Community, which were formed by six countries: Belgium, France, Italy, Luxembourg, the Netherlands, and West Germany in 1951, 1956, and 1958, respectively. In the intervening years, the EU has grown in size by the accession of new member states and in power by the addition of policy areas to its remit. Subsequently, a monetary union, the eurozone, was established in 1999 and is composed of 17 member states.

Currently, ten out of 27 European Union member states remain outside the Eurozone. Then, among seventeen Eurozone countries, there are the core countries that are net payers, proposing changes in the principles regulating the way the Eurozone operates. These core countries have implemented rescue packages for the indebted countries. Germany and France are those mentioned most often as core states, although some analysts include more countries in the group. Another group of Eurozone members consists of the peripheral countries, sometimes referred to as "PIGS" - an acronym for Portugal, Ireland, Greece and Spain, with 
Italy sometimes added. Their present problem is mainly that they are all in substantial sovereign debt, posing threat to the survival of the banking system worldwide. Figures 3-5 present the data for the indebtedness of selected Eurozone countries from 2003-2010 in comparison to the United States and the United Kingdom, in billions of U.S. Dollars.

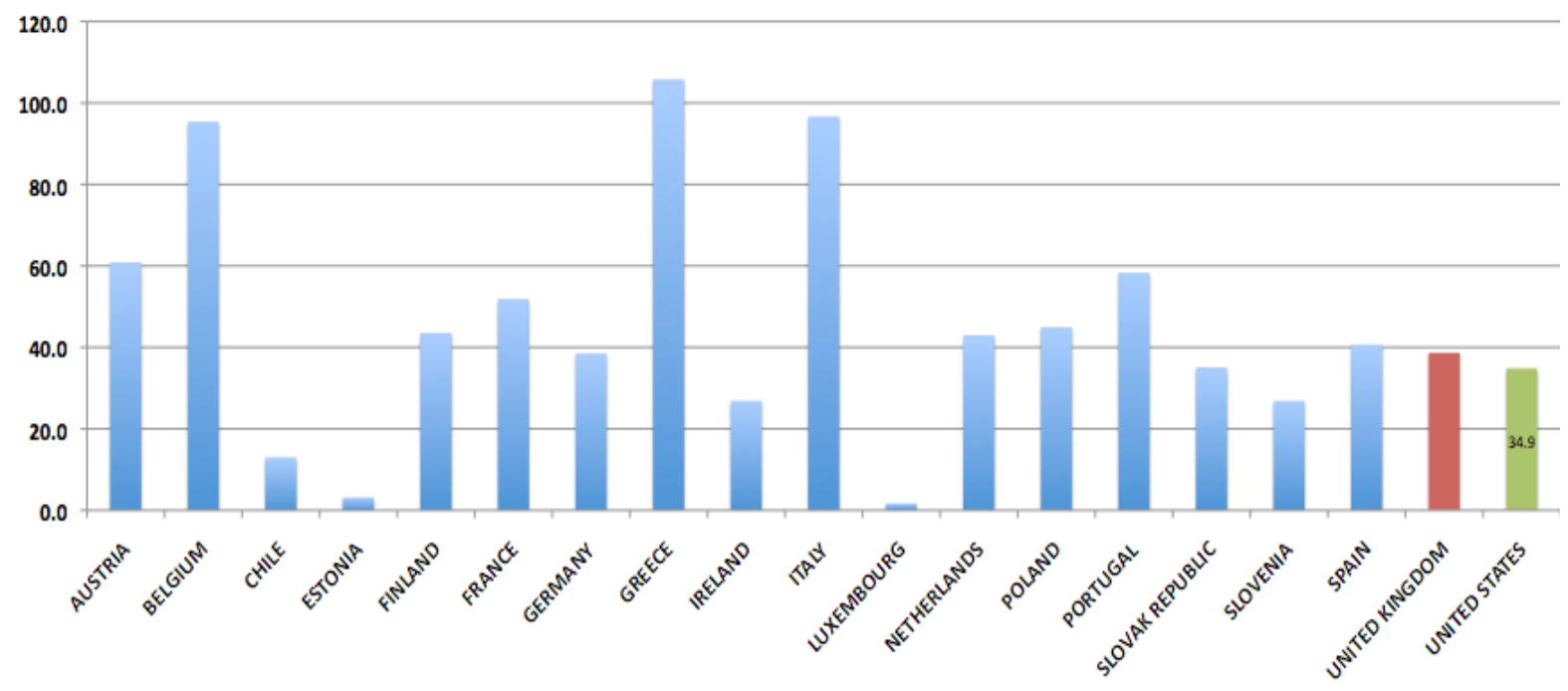

Figure 3: Debt as Percent of GDP in Year 2003

Source: OECD (2011), "Total central government debt", Finance and Investment: Key Tables from OECD, No. 1. Accessed on Feb, 15, 2012.

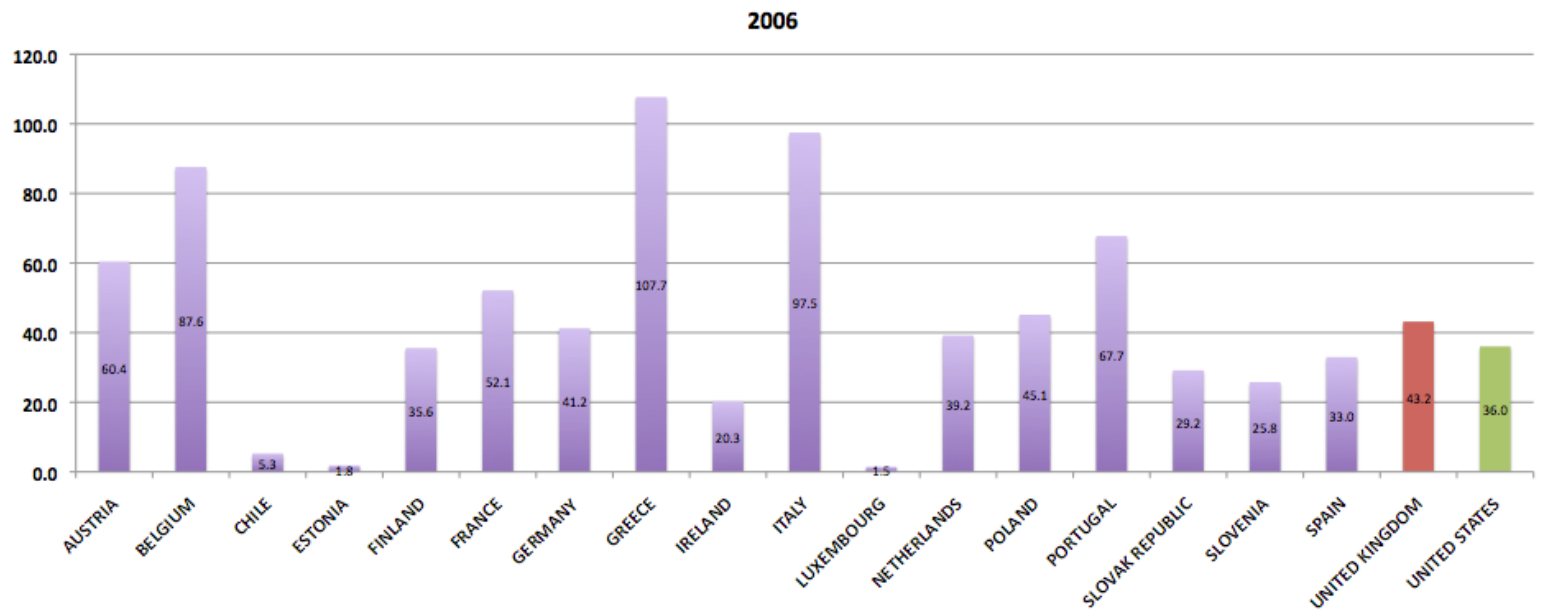

Figure 4: Debt as Percent of GDP in Year 2006

Source: OECD (2011), "Total central government debt", Finance and Investment: Key Tables from OECD, No. 1. Accessed on Feb, 15, 2012. 
2010

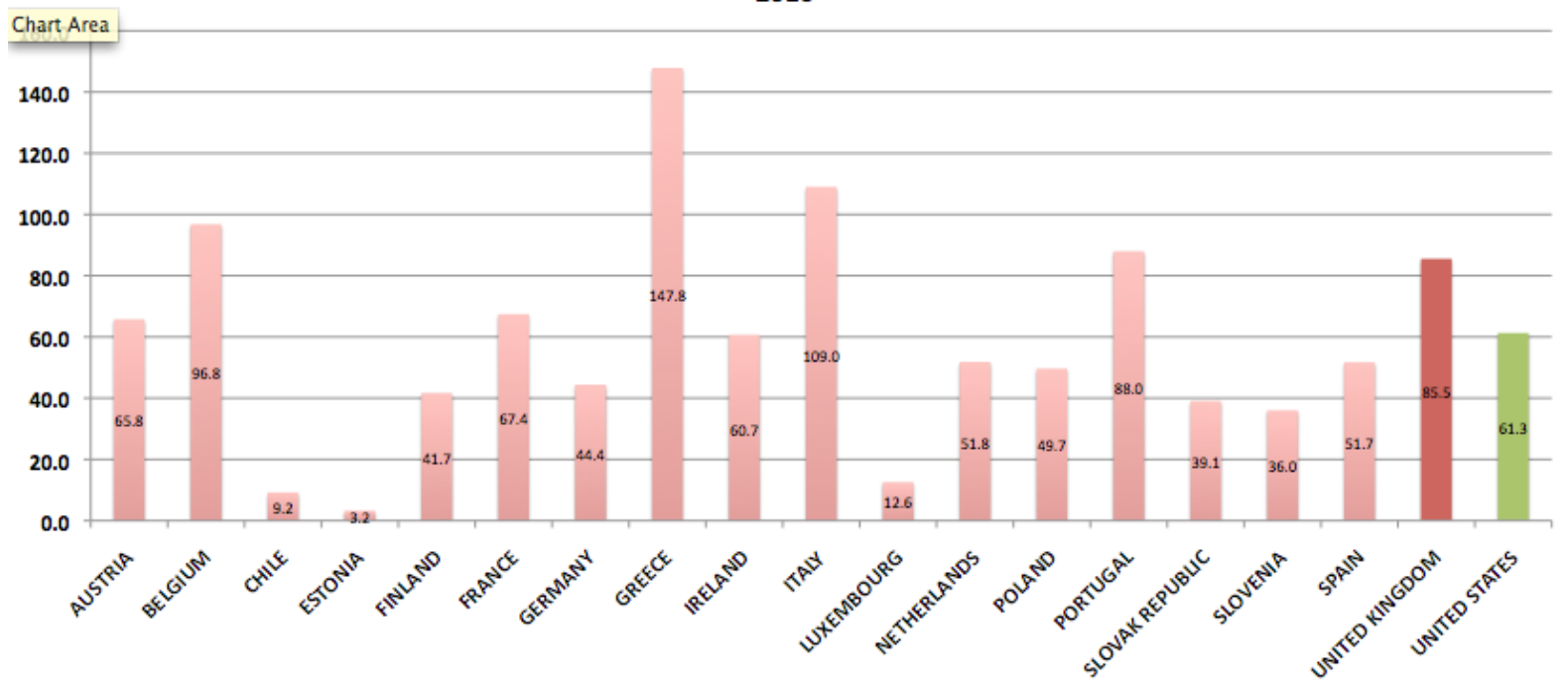

Figure 5: Debt as Percent of GDP in Year 2010

Source: OECD (2011), "Total central government debt", Finance and Investment: Key Tables from OECD, No. 1. Accessed on Feb. 15, 2012.

\section{Eurozone Debt}

Figure 6 demonstrates that debt continues to constitute a serious problem in the Eurozone. Such indebtedness is worrisome since these countries were obliged, on their accession to the Eurozone, to satisfy the Maastricht criteria, also known as the convergence criteria. These requirements, as previously stated, include a low inflation and interest rate, a stable exchange rate, and the satisfaction of fiscal criteria based on low budget deficits and low public indebtedness. Discussion of the negotiations behind the Maastricht Treaty and the associated convergence criteria can be found in Kenen's 1995 book, "Economic and Monetary Union in Europe." 


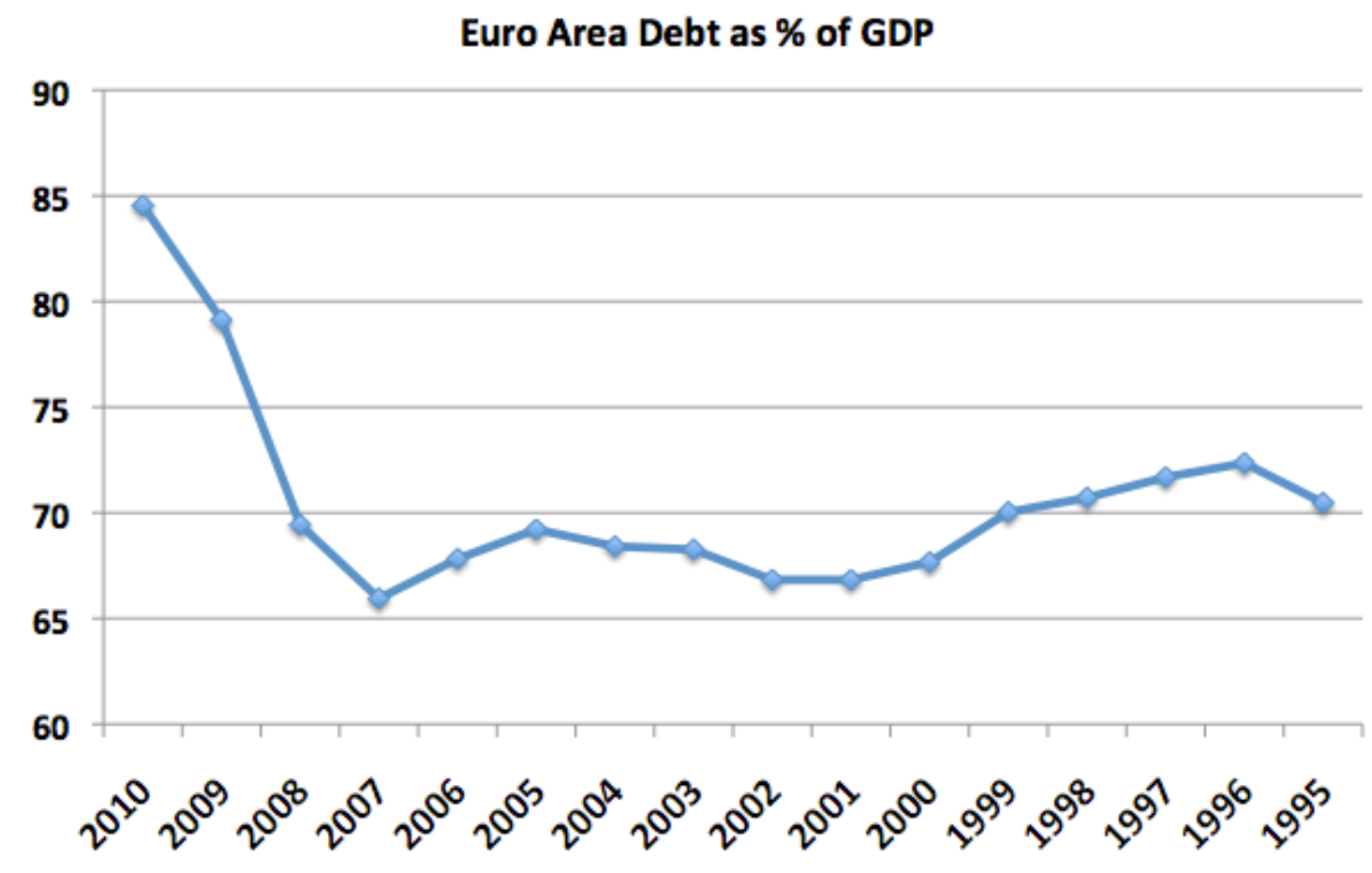

Figure 6: Euro Area Debt As Percentage of GDP Source: Central Bank Debt. (n.d.). European Central Bank Statistical Warehouse. Retrieved February,26,,2012,from:http://sdw.ecb.europa.eu/quickview.do?SERIES_KEY=121.GST.A.I 6.N.B0X13.MDO.B1300.SA.G

These criteria were met, with much effort, by most countries before their accession to the European Union. This was challenging because many of the countries were rooted in a tradition of high inflation and interest rates, large budget deficit, and public debt. Certain balance sheet and budget-related items were "fine-tuned" during the period of adaptation by using some "innovative" accounting procedures. For example, current expenditures were accounted as future ones while future incomes were recorded as current outlays.

However, exceptions were made for countries such as Italy, who could not satisfy the Maastricht Criteria related to its debt to GDP ratio, but was allowed in because of the importance of its economy. The debt to GDP ratio criteria was not an obstacle for Poland which already had a law similar to the Maastricht Criteria prohibiting debt to GDP to exceed 
$60 \%$ prior to joining the European Union (Mundell, 2011). The push to fulfill the criteria is further examined in Obstfeld's 1997 paper, "Europe’s Gamble.”

The accession was followed by a "Euro-banquet." There was a marked increase in consumption and investment. The period of adaptation required sacrifice, and these peripheral countries believed they earned the right to indulge. They increased both consumption and investment. The peripheral "PIGS" countries in particular significantly increased their consumption and decreased savings after joining the Eurozone. Such behavior can be justified if productivity is also experiencing a comparable growth rate. From 19902007, private sector savings in the peripheral countries dropped from $24 \%$ to $14 \%$. However, unit labor costs increased by $32 \%$. This led to a large gap between savings and consumption that contributed to the development of the sovereign debt crisis in the Eurozone 9see, for example, Szyska, 2012).

\section{Admission to the Eurozone}

Figures 7-9 shows the consistent growth in Gross Domestic Product for the various countries after their admission to the Eurozone.

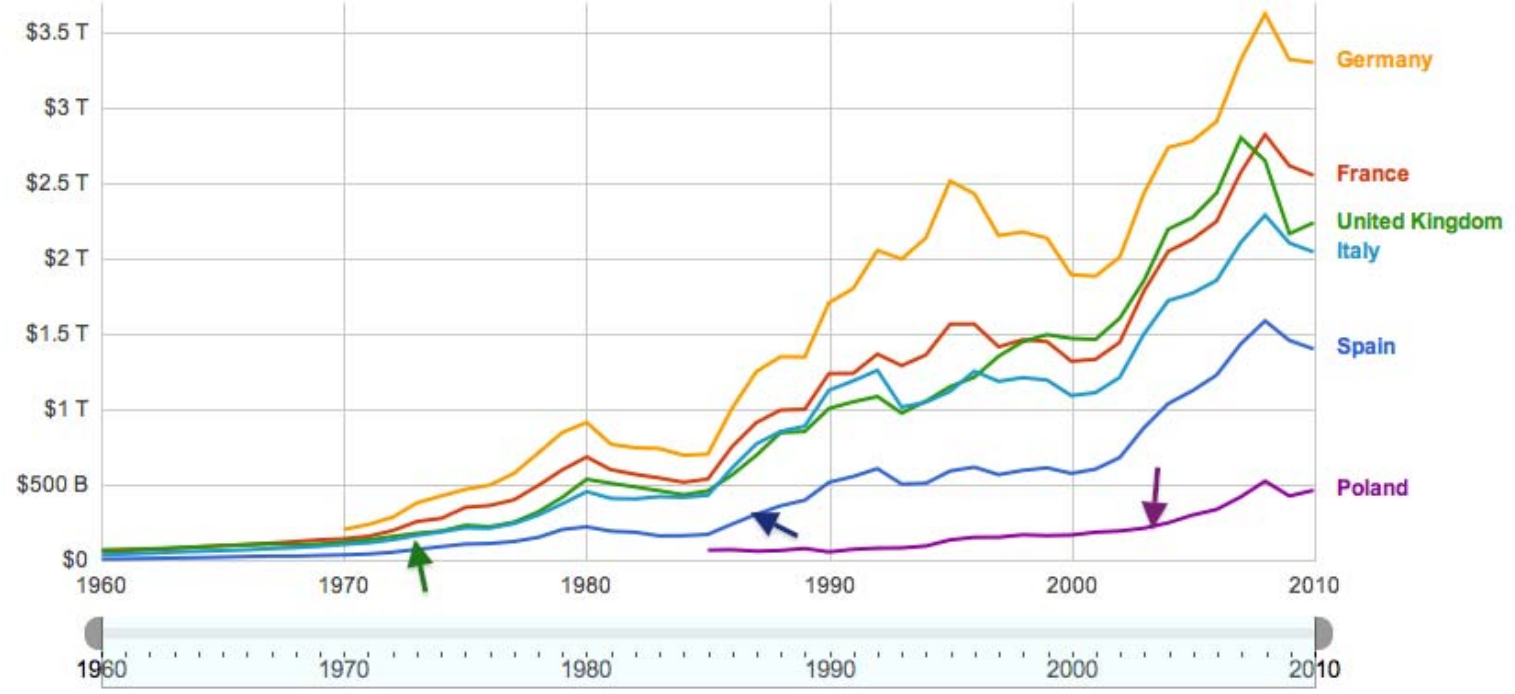

Figure 7: GDP Growth from 1960-2010 for Selected Countries 




Figure 8: GDP Growth from 1960-2010 for Selected Countries

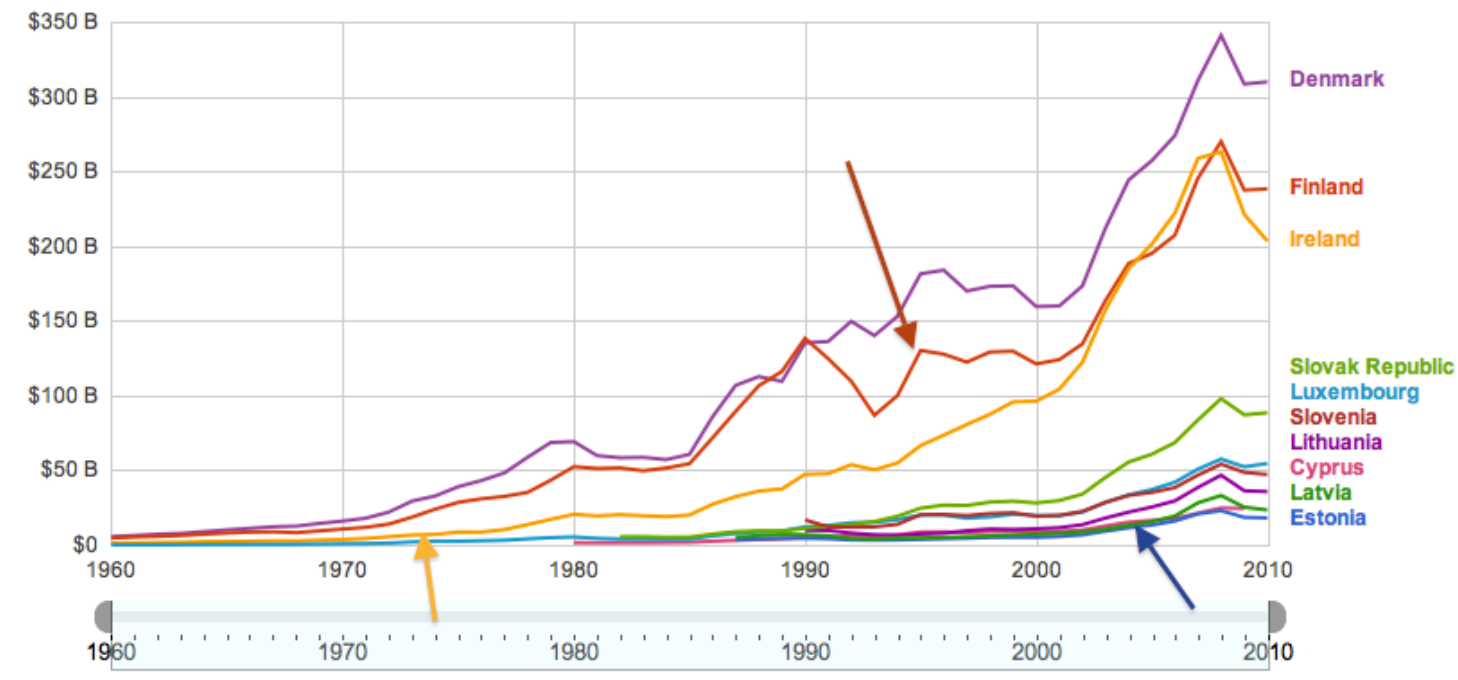

Figure 9: GDP Growth from 1960-2010 for Selected Countries

Source: Gross Domestic Product: Various Countries," The World Bank, World Development Indicators. Last cited: 24 Jan. 2012. Web. 2 Feb. 2012.

The relatively low interest rates in the European Union gave these countries many opportunities for growth. This mindset was largely shared by banks, which were simultaneously giving credits to private sector customers and acquiring government-issued 
securities from countries such as Greece, Ireland, Portugal and Spain. In both cases, recent satisfaction of the Maastricht criterion bestowed a certification of reliability upon these countries, creating an impression that they had made fiscally solid choices. This belief included both the public institutions and the private sectors.

Banks, fundamentally concerned with maximizing profit for a given risk, were interested in giving credits and in acquiring more profitable (i.e., bearing higher interest) government securities from peripheral countries. In effect, there was both a credit and investment boom throughout the entire European Union. The level of credits in the PIGS countries increased, over the years 2003-2009, to between $170 \%$ in Portugal and as much as $350 \%$ in Ireland. Growth of GDP followed, in some cases even exceeding the so-called potential growth resulting from the level of productive factors. This was accompanied by a rising inflation rate and by appreciation of the euro exchange rate. ${ }^{6}$

\section{The Financial Crisis and the EU}

In the financial sphere, prices of financial assets, housing, and land increased. Payment gridlocks resulted, and many businesses lost their financial liquidity. Problems arose as a result of the insolvency of business entities and even of governments. Anxiety about excessive national debt in early 2010 resulted in demands for higher interest rates. This made it difficult for governments to balance and account for new and existing debts, especially in the context of low economic growth. Moreover, much of the debt was with fellow EU member nations, such as Greece and Portugal.

Despite these issues, the EU member states and even the group of peripheral countries are not to be blamed for the problems they experienced. The United States was the principal

\footnotetext{
${ }^{6}$ Euro/ECU Exchange Rates- Monthly Data (Rep.), (2012, February 22). Retrieved February 27, 2012, from Eurostat website: http://epp.eurostat.ec.europa.eu/portal/page/portal/exchange_rates/data/database
} 
source of the financial crisis. The crisis stemmed from the financialization of the American economy and the creation of toxic financial assets, which ended up losing much of their value and creating a lack of trust in the financial markets. Many of these toxic assets were held by European commercial banks which had trusted American financial institutions.

Therefore, many of the problems experienced by the EU, including difficulty with liability repayment, are the result of American actions. Early solutions to the crisis, such as the proposal that European banks should be allowed to fail if they could not repay their debts, also came from the U.S.A. The American point of view regarding the crisis in the Eurozone is considered by some to be bias, rooted in the opinion that, from its conception, the monetary union in Europe had a poor chance of success. The Nobel Prize winner and economist Joseph Stiglitz (2010) observes that "it is going to be extremely difficult now to return from scrambled eggs back to intact ones.” According to Stiglitz (2010), the Eurozone is never going to return to its previous state, and he questions whether the cost of rescuing the Eurozone will be greater than just ending the whole experiment.

However, it seems reasonable to maintain a more reserved attitude than Stiglitz (2010) towards the potential disintegration of the Eurozone. More than once, the Eurozone has managed to overcome crises and emerge as a stronger entity. This may be the outcome of the present crisis. Nevertheless, a number of questions emerge. The creditors of indebted companies and countries are mainly banks and financial institutions based in France, Germany, the Netherlands and other countries (see Table 1). As a result, the collapse of institutions in the PIGS countries would also bankrupt a substantial part of the German, French, Netherlands, Austrian and the Benelux economies. Again, the failure of institutions is apparent.

The countries thus have a common interest, a factor that necessitates implementation of a mutually beneficial rescue or emergency plan. Resources need to be found to bail out the 
PIGS countries. The task is difficult and, in most core countries, controversial. Balcerowicz (2012) believes that massive purchases of government bonds by the European Central Bank would be an even worse kind of bail-out. It would exacerbate the problem of moral hazard as such purchases are potentially unlimited, and would also increase the risk of inflation. More generally, trust in the European Central Bank as guardian of the Euro's stability could be undermined, and the European Central Bank would be granted a powerful new political position with politicians attempting to influence its purchase decisions. It would also further undermine the rule of law in the EU at a time when confidence in the treaties is so crucial. Balcerowicz (2012) maintains that the main solution to the Eurozone crisis lies in properly structured reforms in the affected countries, and claims that experience shows that such reforms offer both short-term and long-term solutions. Statistics suggest that such an aidintervention would require a contribution of at least one trillion euro. This is an enormous sum, extremely difficult to bear for the budget of even the entire European Union. The burden of the operation has mainly been borne by France, Germany, and the Benelux countries, while those standing in line to benefit from financial support include Spain and probably Italy. However, there is a limit of taxpayer tolerance in the countries in charge of bailing out the failing euro economies. 
Table 1:

Exposition of financial assets of PIGS countries in balance sheets of banks from selected countries (US\$ billions)

\begin{tabular}{|c|c|}
\hline Entities & US\$ billions \\
\hline German banks & 512.7 \\
\hline French banks & 410.2 \\
\hline Spanish banks & 117.3 \\
\hline Italian banks & 73.3 \\
\hline Total Eurozone & 1397.6 \\
\hline
\end{tabular}

Source: BIS, 2010

Data presented in Table 1 indicate that it is appropriate for countries shouldered with the bailout burden to demand the balance of the debt alongside explanations for its emergence. The core governments and their institutions are also at least partially to blame. After all, once the Eurozone was established and demand for credits and capital skyrocketed in the PIGS countries, the core countries' institutions failed to implement the necessary supervision or coordination of the economic policies of the PIGS countries.

In fact, the core countries seemed to overlook the high economic and financial risk of Portugal, Ireland, Greece, and Spain. Worse yet, Berlin, Paris and Brussels turned a blind eye toward the authorities of Greece, Ireland and Portugal as they "tuned up" their balances and official statistics, even at the stage of their accession to the European Union. At the same time, one has to remember that the EU was mainly a political project. Otherwise, Greece, and the other countries, would have had to wait longer before becoming a part of the common European currency. 
Mundell (2011), like many others, holds that the prestige of being in the Eurozone can provide additional motivation for countries such as Greece to overlook problems in their spending. For example, they hiked pension plan expenditures to the level of Germany even though their per capita income was only a fraction of 1/3 of Germany's. Joining the Eurozone exponentially increased the moral hazard of Greece because it rationalized that the Eurozone community would never let Greece fail. In essence, countries can fall into the trap of going on a "fiscal binge" as Mundell puts it because they assume that their expenses can never exceed the massive budget of the Eurozone. This process of creating more institutions to overcome or essentially to hide the failures of other institutions is what one call the Institutional Spiral.

Currently, the EU contains many different economic traditions and policies. There are many who live by the mantra, "First we work, then we save, and then we invest." Conversely, there are those who say, “first we'll consume, then we'll invest what is left, if any, and in case something still remains, we'll save it." Two very different worlds are trying to $\mathrm{c} 0$-exist alongside each other. Consequences of aggressive real estate investments made by investors from the PIGS countries are also felt in Poland. Some investors purchased land, factories and buildings under the assumption that prices would go up because Poland, along with other Central and Eastern European countries, became a European Union member state. They hoped to capitalize on the principle of price equalization, according to which assets would increase about twenty percent.

The idea was to take credit in Eurozone-based banks which bore interest rates of a few percent and invest in assets whose rates of return seemed substantially higher. The idea was sound in theory, but reality deviated from the hypothesized course. The financial crisis born in the real estate markets in the United States had repercussions in the EU. The crisis caused prices in real estate markets to fall, severely limiting chances to achieve expected rates of 
return on investments. Consequently, a large number of businesses in PIGS countries experienced problems with their liquidity and solvency.

What is the remedy to this situation? Does the Eurozone have any real chance of survival and further growth? Will the Euro be able to continue as an international currency?

These questions cannot easily be answered. Proposed solutions are numerous and often contradictory. It is helpful in analyzing these proposed solutions to recall the historical and political context of the Eurozone, from its formation to the present. Remember that the foundation of the Eurozone was based on political as well as economic motives. These political motives included, among others, the will to deepen integration within the European Union, a goal considered achievable only with the adoption of a single common currency.

Additionally it was Europe's intent to stabilize the global financial system, hitherto based upon only the dollar. After the Asian crisis of late 1990s revealed weaknesses in the dollar-based global financial system, it seemed appropriate to propose a financial system based upon another international currency in addition to the US Dollar.

Another political motive for the creation of the Eurozone was the wish to weaken West German currency, the Deutsche Mark, and to control the strong, united German state. Paradoxically, Germany also favored the idea in the expectation that the new common currency would be weaker than the Deutsche Mark. Germany hoped that the adoption of the euro would improve the state's competitiveness following the burden of the unification process, a burden aggravated by the introduction of a strong national currency.

The Eurozone deepened the processes of integration in the European Union and stabilized the global financial system. For the first dozen years, the euro was a solid and stable currency, with the most stable prices in fifty years. The average inflation in Euroland amounted, over the last 12 years, to c. $1.97 \%$ and the average level of inflation in Germany to c. $1.5 \%$. Budgetary deficit (on average) at the end of 2011 was at around $4.5 \%$, while 
budgetary deficit exceeded $10 \%$ in both the United States and Japan. Admittedly, some Eurozone countries fared worse than others, but as a whole it cannot be said that the Eurozone performed poorly.

We can conclude from the data presented that the Eurozone is not homogeneous concerning financial or fiscal policy. This diversification gives rise to policy divergence regarding the best method to remedy the present situation and prevent a similar situation in the future.

\section{Eurozone’s Scenarios}

According to P. Krugman, there are four scenarios for overcoming the present state of affairs in the Eurozone. While theoretically possible, they are difficult to implement in their pure form. Scenario one recommends applying a restrictive financial policy to the Eurozone, especially regarding fiscal policy. This would consist of strict control of budgetary expenditure, cuts of budgetary outlays, and, where practicable, an increase in budget income.

The troubles in Europe are not part of a currency or monetary crisis. In fact, the euro exchange rate has been appreciating against US Dollar since about third quarter of 2001, and businesses keep more and more euro as foreign currency reserves - at present close to $30 \%$. Rather, it is a crisis of economic policy and inadequate political and economic institutions. Considering this, it is hardly surprising that Krugman and other experts call for strict budget controls and discipline in the field of public debt as these are seemingly obvious remedies. However, stern fiscal policy means that something has to be taken away from somebody.

From who, then, and where? Budgetary cuts would mainly target three areas, namely, education, healthcare and pension funds. In addition, it would be necessary to increase taxes and cut wage rates in the public sector. The experience in Greece shows how painful this can 
be in practice. The Greek riots stopped just shy of letting the monuments of Athens go up in flames.

On the other hand, historical perspective provides examples of successful implementation of restrictive fiscal policy. Several years ago restrictive fiscal policy was applied in Baltic countries with considerable success. Budgetary and public debts were reduced, exchange rates of local currencies were stabilized, and inflation was decreased. Economies of the region stabilized enough to allow Estonia to meet the Maastricht criteria and become a part of the Eurozone. This example demonstrates that a policy of compulsory savings is not necessarily doomed to failure.

Scenario two involves the restructuring of the debt. Debt restructuring would reduce all of the debts of the PIGS countries and their indebted entities. This program is already underway in Greece. The restructuring program is implemented based on the assumption that the debt weighs down upon both debtors and creditors, since both were initially overoptimistic in borrowing money and giving credits. Problematically, this prompts other countries and businesses to demand debt restructuring. While, formally, they might not belong in the Eurozone, their trade exchange with the Eurozone accounts for such a significant share that they hope to be regarded as part of it. Of course, it is impossible to satisfy the demands of all interested parties. Consequently, this second scenario also has little chance of success, even though it cannot be totally ruled out.

Scenario three is referred to as the "Argentinization of Europe," initiating changes similar to the policies in Argentina just over a dozen years ago. The Argentinean peso was devalued with respect to US Dollar in order to improve the competitiveness of Argentina's economy, stimulating business activity and increasing income to the state budget. Is this scenario relevant to the European Union? This worked for Argentina, but it is not a practicable solution for Europe. Recalling the political motive for the establishment of the 
Eurozone, one must realize the importance of the euro and the Eurozone as stabilizing forces in the global economy, due to the possibilities of investing financial assets either in the US dollar or in the euro. As a result, devaluing the euro would not only mean destabilization of the Eurozone, but also destabilization of global finance and global politics.

Devaluation of the euro is even more incomprehensible given that, as mentioned before, the problem in the Eurozone is not a currency crisis. Additionally, there are still stable countries in the Eurozone despite the strong currency. The German economy has been the prime example until recently when it failed to sell a large portion of its ten-year bonds (just 40 percent of the issue was sold). The economy of Germany is not totally immune to the unstable financial markets, and the same goes for the Benelux countries and France. Still, the risk inherent in devaluation scenario is excessive, and the costs of launching the policy could be extreme.

Scenario four, known as "Europe's Resurrection," is based on the assumption that the states of Europe must return to a community-wise manner of thinking, a viewpoint of solidarity. The individual states succumb to nationalist and individualistic tendencies. Sooner or later, Europe is going to have to face the vital question of whether to evolve as a confederation or a federation. This will take profound political changes. Adequate institutions will have to be instated to take responsibility for the supervision and coordination of the economic and fiscal policy of the European Union member states.

It is quite unlikely, however, that all countries will behave with equal decency and truly care for stabilization of the European Union through responsible fiscal and social policy. Therefore, it might be advisable to consider a common governance institution, such as an Agency of European Finance. The operations of such an agency or ministry are debatable. Should an agreement be reached between all countries interested in a coordination of 
budgetary policy at the level of their national parliaments? Can an agreement even be made about a new regulative institution at this level?

Present dilemmas, such as apprehension over the restriction of state sovereignty, would be multiplied. This confronts us with the pivotal question: which Europe do we want? Do we want to have a single strong European government or separate national governments? The essence of the problem is in the implementation of a German-French concept concerning fiscal union. Such a fiscal union would effectively mean that a certain part of budgetary policy would be transferred from the national onto the community level. Put another way, this would entail giving up narrowly perceived national interests. It seems worthwhile to adduce the example of The United States in this context.

The United States is engineered so that, should Alabama, California, or Mississippi face serious hardship while New Jersey or another state fare fine, federal taxes are sent to Washington D.C and subsequently sent to the states most badly in need. America thus reveals a strong tradition of solidarity. However, in Europe there is no consensus about the need to build the Union based upon solidarity transfers. On the contrary, net payers view this proposal as out of the question. In addition, it is unclear how the hypothetical fiscal institution would operate. The agency could not completely overshadow national parliaments on areas such as the state budget, but then its strength would be largely diluted. These are the doubts and dilemmas that will plague this potential solution unless a concept with appropriate legal and administrative formula is adopted.

This leaves us with scenario five, which Krugman did not address. It is perhaps even more illusory but should nonetheless be taken into account. Many countries have substantial reserves in foreign currencies, including China and some Islamic countries. The Chinese have proposed opening European borders so that the Chinese can buy out European debt and help manage it. Such a solution would drastically alter the global economic landscape and the 
distribution of relative economic power. With the West in its weakened state, new power would be distributed among China, India, and perhaps Brazil and South Africa, resulting in far reaching repercussions.

Regarding the future of the Euro, it is not time to plan the currency's demise. First, in spite of the present problems in Euroland, the condition of the euro is quite good. The euro will survive even if Greece or Portugal decides to leave the Eurozone, a highly implausible prospect. The euro will exist as long as there are core countries interested in strengthening, consolidating and developing it. The following factors demonstrate that the core countries will remain concerned about the euro:

- The Eurozone ensures states' access to large and wealthy sales markets,

- The Eurozone ensures economic, financial and political stabilization, both in Europe and worldwide,

- Membership in the Eurozone conveys an indisputable prestige upon members,

- Quitting the Eurozone would cause economic, financial, and social turbulence in the deserting country as well as the Eurozone. For example, should Greece leave, its new currency would be greatly devaluated. This would further deteriorate the living standard in Greece and decrease the imports of goods and services from other Eurozone countries, worsening the economic condition of exporting countries. No party to the game is thus interested in Eurozone disintegration.

Aside from Krugman, many other economists also agree that the austerity measure applied today in the Eurozone is actually the best solution. As the dominant economic power in Europe, Germany had its history of heavy growth and stagnation. 


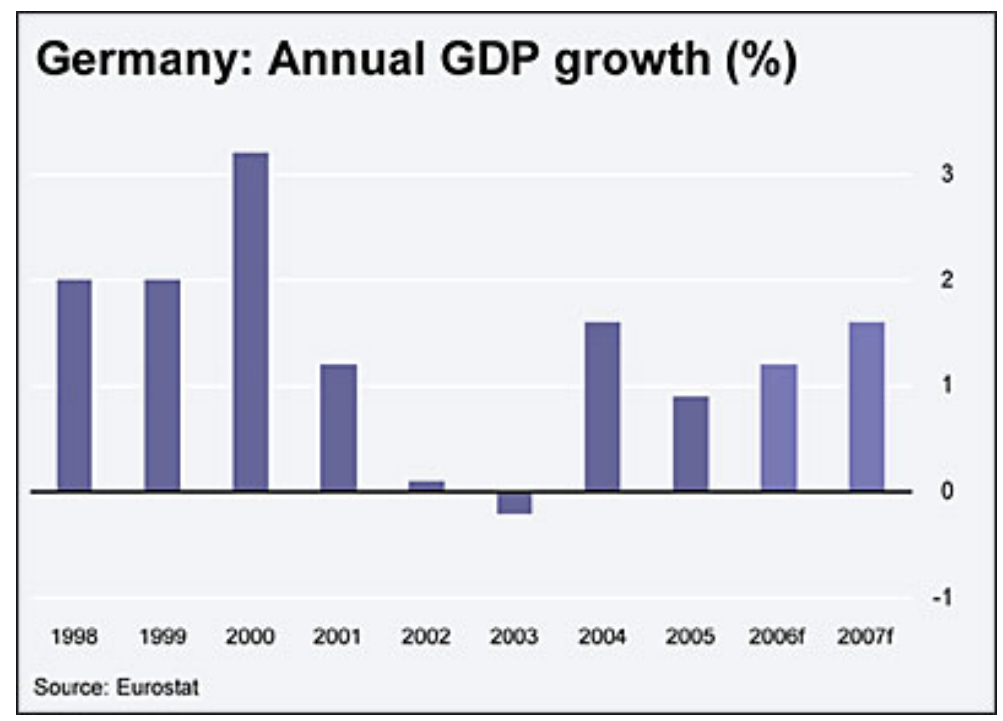

Source: German Growth Will Remain Sub-optimal, Forbes.com, May 2006. Oxford Analytic

The austerity measures proposed by Germany today are similar to those applied in the past. Germany tightened its budget and tried to pass local laws to improve business competitiveness. Germany also changed its unemployment benefits system to promote productivity. The new system discouraged workers to retire early, and encouraged some of the workers in the labor force to take low paying jobs. This effort cut the expense of unemployment benefits and reduced the unemployment rate at the same time. It is not a winwin solution, but in the end, more people were able to get jobs, pay taxes and contribute to GDP.

The belt-tightening measure also helped Germany avoid the housing bubble problem. The German government required a $40 \%$ down payment for every house mortgage. The German government also saved money from the taxes collected while improving the efficiency of government offices and passing regulations to increase productivity. Germany invested the money it saved in education. The bottom line is: Germany tightened down on both the demand and supply. 
Today, Germany can enjoy the fruits of its labor by showing economic growth despite the crisis all over the world. Having learned from its own history, Germany is now pushing Greece to do the same.

From this point of view, saving the Eurozone is not going to be an instant measure. What is happening in Greece is a result of long-term excessive expenditure and decline in growth. Paul Krugman suggested killing the Euro (Killing The Euro, Op-Ed Columnist NYTimes. December 1, 2011), but Germany and other Euro economic owners are trying to save the Euro by applying a long-term solution. Greece will default if it does not get a bail-out, but the effect is bigger than just Greece. If Greece isn't saved, and Spain and Italy end up defaulting as well, Germany itself will be hit with a bigger recession or it may even fail.

At this point, no remedy is good for everybody. Whether it's the short term solutions proposed by Krugman or long term solutions proposed by Germany and France, Europe will suffer for the next few years. Until innovation and productivity in the Eurozone are restored, the European countries will remain non-competitive and stagnant.

\section{Conclusion}

The European Commission and the European Parliament are interested in the survival of the Eurozone. Establishment and operation of the Eurozone has strengthened these institutions by lending additional legitimacy to their existence and development.

The United States is interested in the maintenance of the Eurozone as well. Why? The euro has become a stabilizing force in contemporary world finance. The euro can enable the coexistence between the Eurozone and US Dollar Zone and opens prospects for further economic growth.

Of course, one might be tempted to ask whether these two pillars of global economy, one based upon the US dollar, another one upon euro, shall suffice. Is a third one going to 
appear, Asian perhaps? This remains to be seen. The idea of replacing Adam Smith as the father of the free market economy in academic textbooks with a communist party secretary is incomprehensible to Europeans. 


\section{References}

Anderton, Alain (1977). Economics. Patparganj, Delhi: Pearson Education.

Balcerowicz, L. (2012). Eurozone I: Bail-outs are no substitute for reforms. Europe's World, Spring 2012, 75-77.

Bomberg, Elizabeth, John Peterson, and Richar Corbett, eds. (2012) The European Union: How Does it Work? (3rd ed) (Oxford, England: Oxford University Press, 2012). ISBN 978-019-957080-5 and ISBN 0-19-957080-9.

Bordo, M. and James, H. (2010). A long-term perspective on the euro. In The Euro the first decade. Cambridge: Cambridge University Press.

De Grauwe, P., \& Mongelli, F. P. (2005). "Endogeneities of Optimum Currency Areas: What Brings Countries Sharing A Common Currency Closer Together?” (ECB Research Paper Series - Working Papers) (Germany, European Central Bank). Frankfurt. Retrieved January 29, 2012, from http://papers.ssrn.com/sol3/papers.cfm?abstract_id=691864

De Grauwe, P. (2009). Economics of monetary union. Oxford: Oxford University Press.

De Grauwe, P. (2009). The Politics of the Maastricht Convergence Criteria. Retrieved August 20, 2012 from http://www.voxeu.org/article/politics-maastricht-convergence-criteria

Dellas, Harris and George S. Tavlas (2009). An optimum-currency-area odyssey. Retrieved February 28, 2012, from http://www.bankofgreece.gr/BogEkdoseis/Paper2009102.pdf 
European Central Bank. (2012) European Central Bank Debt. European Central Bank Statistical Warehouse. Retrieved February 26, 2012 from:

http://sdw.ecb.europa.eu/quickview.do?SERIES_KEY=121.GST.A.I6.N.B0X1

European Central Bank. (2012) European Central Bank Interest Rates-Annual Data. ECB Statistical Data Warehouse. Retrieved February 26, 2012, from

http://sdw.ecb.europa.eu/home.d

European Central Bank. (2012). Euro area HICP statistics. ECB Statistical Data Warehouse. Retrieved February 26, 2012, from http://sdw.ecb.europa.eu/home.do

European Commission. (2012) “Economic and Financial Affairs” Retrieved from:

http://ec.europa.eu/economy finance/euro/adoption/who can_join/index_en.htm

Eurostat. Euro/ECU Exchange Rates- Monthly Data (Rep.). (2012, February 22). Retrieved February 27, 2012, from:

http://epp.eurostat.ec.europa.eu/portal/page/portal/exchange_rates/data/database

Eurostat. Your Key to European Statistics. (n.d.). Retrieved January 29, 2012, from http://epp.eurostat.ec.europa.eu/portal/page/portal/eurostat/home/

Feaster, Seth W., Nelson D. Schwartz, Tom Kuntz (2011-10-22). "It's All Connected-A Spectators Guide to the Euro Crisis". New York Times (Nytimes.com). Retrieved 2012-0514. 
Kenen, P. (1969). 'The Theory of Optimum Currency Areas: An Eclectic View' in Monetary

Problems of the International Economy, R. Mundell and A. Swoboda (eds.), (Chicago: University of Chicago Press) 41-61; reprinted in Exchange Rates and the Monetary System:Selected Essays of Peter B. Kenen, Aldershot: Edward Elgar (1994): 3-22

Kenen, P. B. (1995). Economic and monetary union in Europe: Moving beyond Maastricht. Cambridge, England: Cambridge University Press.

Koba, Mark (2012-06-13). "CNBC-Europe's Economic Crisis-What You Need to Know-Mark Thoma -June 13, 2012". Finance.yahoo.com. Retrieved 2012-07-07.

Friedman, Milton (1953), "The Case for Flexible Exchange Rates," by Milton Friedman, published in Friedman's Essays in Positive Economics, University of Chicago Press, 1953, pp. 157-203.

Krugman, P. (2011, January 12). Can Europe Be Saved? New York Times Magazine. Retrieved February 26, 2012, from http://www.nytimes.com/2011/01/16/magazine/16Europe$\underline{\text { t.html?pagewanted }=\text { all }}$

Lewis, Michael. (2011), "How the Financial Crisis Created a New Third World" on National Public Radio. Retrieved 2012-07-07 from Npr.org.

McKinnon, R. (1963), Optimum Currency Areas, American Economic Review, 53: 717-24. 
Mundell, R. Poznan University of Economics Review. 1st ed. Vol. 11. Poznan: Poznan University of Economics, 2011. 7-27.

Mundell, R. A. (1961). A Theory of Optimum Currency Areas. American Economic Review, 51(4), 657-665. Retrieved January 29, 2012, from

http://links.jstor.org/sici?sici=0002-

8282\%28196109\%2951\%3A4\%3C657\%3AATOOCA\%3E2.0.CO\%3B2-V

Nowak, A. Z., \& Ste pniak, A. (2003). Strefa euro - wyzwanie dla Polski. Warszawa: Wydawn.

Nauk. Wydziału Zarza dzania Uniwersytetu Warszawskiego.

Nowak, A. Z., \& Tchorek, G. (2007). European economic integration: Chances and Challenges. Warsaw: Wydawnictwo Naukowe Wydziału Zarza dzania Uniwersytetu Warszawskiego.

Obstfeld, M. (1997). Europe's gamble. Brookings Papers on Economic Activity 2, 241-317.

Ryć, K. (2006). Jak szybko do euro? In Zrównowaz ony wzrost gospodarczy: Rola polityki finansowerj : Polska droga do euro. Warszawa: Wydawn. Naukowe Wydziału Zarza dzania Uniwersytetu Warszawskiego.

Scitovsky Tibor (1958), Economic Theory and Western European Integration. 
Stiglitz, J. E. (2010, May 5). Can the Euro be Saved? Project Syndicate. Retrieved January 29, 2012, from http://www.project-syndicate.org/commentary/stiglitz125/English

Szyszka A. (2012, March). Economic and Behavioral Aspects of the Euro Crisis.

Retrieved April 2, 2012, from

http://www.caseresearch.eu/sites/default/files/Economic\%20and\%20Behavioral\%20Aspects $\% 20$ of $\% 20$ the $\% 20$ Euro\%20Crisis.pdf

Weisbrot, Mark and Juan Montecino. (February 2012). "More Pain, No Gain for Greece: Is the Euro Worth the Costs of Pro-Cyclical Fiscal Policy and Internal Devaluation?" Center for Economic and Policy Research. Retrieved September 6, 2012 from http://www.cepr.net/index.php/publications/reports/more-pain-no-gain-for-greece

World Bank. Gross Domestic Product: Various Countries. World Development Indicators. Last cited: 24 January 2012. Web 2 February 2012. 